\title{
The Relationship of Training Effectiveness, Emotional Intelligence and Work Motivation on Performance
}

\author{
Syamsul Huda $^{1}$, Suparno Eko Widodo ${ }^{2}$, Widodo Sunaryo ${ }^{3}$ \\ Post Graduate Program, Universitas Pakuan Bogor, Indonesia
}

\begin{abstract}
The aim of this study is to examine the relationship of training effectiveness, emotional intelligence and work motivation to performance either individually or jointly. Variables of training effectiveness, emotional intelligence and work motivation serve as independent variables while the dependent variable is performance. The study was conducted on randomly selected 435 public servants in 32 of regional work units in the city of Jambi, Indonesia. Using mix method, a sequential explanatory design is applied where quantitative come first. The study both quantitatively and qualitatively reveals that there is a positive significant relationship among variables under the following distribution of coefficient of correlation: effectiveness of training to performance $=0.639$, emotional intelligence to performance $=0.552$, work motivation to performance $=0.614$ and when tested together it produces coefficient of correlation $=0.932$ and coefficient of determination $=0.868$ indicating the existence of other $13.2 \%$ variables not including in the model affecting performance within the public servants' working environment.
\end{abstract}

Keywords: training effectiveness, emotional intelligence, work motivation, performance

\section{INTRODUCTION}

In line with the need for service-oriented to the interests of society as a logical consequence of decentralization, government bureaucracy faces various challenges requiring every local government employees can handle it in accordance with the local conditions including in Sarolangun Regency, Jambi Province, Indonesia whose current performance still needs improving. Government Sarolangun exercising regional autonomy rights is required to be more intelligent in facing obstacles and challenges especially in managing the natural resources and sources of finance as well as the enforcement of popular sovereignty as a manifestation of democracy according to the demands and growing aspirations.

The results of a preliminary survey conducted to some officers serving various regional working unit in Regency Sarolangun only obtained the average score of $18.33 \%$ indicating low performance even though these officers have undergone official trainings conducted by the local government. This needs handling and more serious effort must be conducted in order to be able to realize the better service excellence and more sustainable.

Based on this, as an effort to improve performance, it is necessary to conduct an effective training. The effective training is aimed at developing emotional intelligence through a continuous and programmed training. This is conducted due to the nature of performance which is fluctuate in accordance with changes in circumstances that occur. This way, it is necessary to provide a suitable training which is capable of generating significant and sustainable work ethic for people working in the organization.

Improving the quality and quantity of work with the right target, amount and time can be realized optimally when emotional intelligence in organizations is managed properly so that the organization will avoid the stagnation and even from setbacks. Therefore research on performance, training effectiveness, emotional intelligence and work motivation is needed to provide guidance and reference for interested parties in maintaining and increasing the performance of the organization in accordance with intended purpose which is the common goal of all stakeholders in the organization.

Realizing the importance of aforementioned factors, then the problem in research is formulated as follows:

1. Does training effectiveness positively affect performance? 
2. Does emotional intelligence positively affect performance?

3. Does work motivation positively affect performance?

4. Do training effectiveness, emotional intelligence and work motivation altogether affect performance?

\section{LITERATURE REVIEW}

The literature will highlight variables affected the performance of employees in the area of training effectiveness, emotional intelligence and, work motivation together with the dimensions forming these variables.

According to Gibson (2012) individual performance is the basis for organizational performance. Furthermore, they described that performance is closely related to the behavior of an individual and is influenced by various factors such as (a) the individual variables, consisting of abilities and skills, the background of a person's life including family, experience and social class; (b) psychological variables, consisting of: motivation, attitude interpersonal communication, perception and learning; (c) organizational variables, consisting of: leadership, organizational resources, organizational structure, and so on. Colquitt et.al (2009) states that the performance is the value of the behavior of workers who contribute positively or negatively towards the achievement of organizational goals.

According to Noe et.al (2011) training is a business' organization plans to help employees acquiring knowledge related to jobs, skills, abilities, and behavior with the aim of implementing ability this job. Factors included: a. knowledge, b. skills, c. capability, d. improvement of behavior and e. application. Gibson et al (2012) argues that effectiveness is the accomplishment of a recognized objectives of cooperative effort". Effectiveness is defined as the degree of success in achieving the goals set by two main factors, namely: a. success rate, b. pre determined interest.

Emotional intelligence according to McShane \& Von Glinow (2010) is a set of characteristics that underlie the expression of emotions, assimilate emotion in thought, understand the reasons and regulate emotions in oneself and others. According Kreitner \& Kinicki (2008) emotional intelligence is management / self-management in dealing with others in a mature and constructive manners. The factors consists of two parts: personal competency and social competency.

Gibson (2012) stated that the motivation is characterized with (a) direct from behavior, (b) the strength of the response once an employee chooses to follow the action, and (c) persistence behavior. Furthermore Colquitt, Lepine, and Wesson (2009), define motivation as a set of energy forces originating both inside and outside employees, determine the direction, intensity, and persistence. Various theories emphasized that there are three elements of motivation, (a) attempts; (B) the organization's goals; (C) requirement. This element is a measure of the intensity of the effort, in this case, if a person is motivated to do his job he will not bend over backward so that high effort will produce outcomes. Thus, work motivation means a push of a person's desire to carry out actions or activities within the scope of the tasks of the job / position within an organization.

With particular reference to above theories, the following hypothesis is formulated:

1. Training effectiveness positively affects performance.

2. Emotional intelligence positively affects performance.

3. Work motivation positively affects performance.

4. Training effectiveness, emotional intelligence and work motivation altogether affect performance.

\section{Data Collection}

This study applies mix method with direct observation to the field aimed at analyzing the phenomenon occur when the research took place then confirm the finding by using direct depth interview. This way, writers apply Sequential Explanatory Mixed Methods. Descriptive statistics and quantitative analysis are used for finding an initial solution to the problem encountered. The sample of this study were 435 government employees completed leadership development program located in 32 (twelve) regional working units in Sarolangun Regency, Jambi Province, Indonesia.

Techniques of data collection in this study are in the form of a questionnaire. The normality assumption is prerequisites to proceed to further test. The analysis is conducted with multiple linear regression and hypothesis testing is performed at a significance level of 0.05. 
Depth interview with head of departments were performed to confirm the result of quantitative findings. The implication of the research findings is then discussed.

\section{RESUlT AND DisCUSSION}

The teachers of listed organizations were asked to participate in the survey by responding their opinions in different measures of Training Effectiveness, Emotional Intelligence, Work Motivation and Performance. The normality is performed with Lilliefors test. Data are normally distributed as the value of each variable is not exceeding the critical value for Lilliefors test. The Lilliefors normality test values for Training Effectiveness, Emotional Intelligence, Work Motivation to Performance are $0.571,0.599$ and 0.599 respectively below the critical value of 0.613 for $n=435$.

\subsection{The Effect of Training Effectiveness on Performance}

Hypothesis testing confirms that training effectiveness positively affects performance with correlation coefficient value of 0.639 and the coefficient of determination $=0.408$. This means that $40.8 \%$ of employees' performance is determined by training effectiveness while the other $59.2 \%$ is contributed by other variables. Similarly, the result of qualitative research interviews, observation, and documentation in thirty two regional working units in Sarolangun Regency, Jambi Province, Indonesia, confirms the tendency of the relationship between training effectiveness and employees' performance. This finding strengthens the quantitative research hypothesis results testing that there is a positive significant relationship between training effectiveness and employees' performance.

This is consistent with the theory put forward Gibson et.al (2012) stating the performance is 'outcomes' of a work in accordance with the organization's objectives to be achieved. Also Colquitt, Lepine and Wesson (2009) stated that the performance is the value of the behavior of workers who contribute positively or negatively to the achievement of organizational goals.

Previous relevant research results also show that the effectiveness of training has a positive influence to performance (Sultana et. al, 2012) . The conclusion of this study is that the appropriate investment for an organization is to implement an employee training with the changing in technological innovation, marketing competition, organizational structure and other important activities that training, employee performance, salary and job involvement are the keys to improve employee performance.

Based on above description, it is concluded that the higher the effectiveness of the training, the higher the performance results. Thus the findings of facts and data in this analysis further supports previous findings on the relationship between the effectiveness of training to performance.

\subsection{The Effect of Emotional Intelligence on Performance}

Hypothesis testing confirms that emotional intelligence affects performance with the correlation coefficient value of 0.552 and coefficient of determination $=0.304$. This means that $30.4 \%$ of performance is determined by emotional intelligence while the other $69.6 \%$ is contributed by other variables. By the same token, the result of qualitative research interviews, observation, and documentation in thirty two regional working units in Sarolangun Regency, Jambi Province, Indonesia, confirms the tendency of the relationship between emotional intelligence and employees' performance. This finding enforces the quantitative research hypothesis results testing that there is a positive significant relationship between emotional intelligence and employees' performance.

The above condition is reinforced by the theory put forward by Maria Jose Sanchez-Ruiz et.al (2010), which suggests that the trait emotional self-efficacy is defined as a constellation of emotions associated with self-perception and disposition located on the lower level of the hierarchy of personality.

Results of previous relevant studies have shown that emotional intelligence has a positive influence to the performance (Atta et.al, 2013). The higher the emotional intelligence, the higher the performance. Thus the findings of facts and data in this analysis further supports previous findings on the positive influence of emotional intelligence to performance.

\subsection{The Effect of Work Motivation on Performance}

Hypothesis testing confirms that work motivation positively affects performance with the coefficient of correlation $=0.614$ and coefficient of determination $=0.374$. This means that $37.4 \%$ of 
performance is determined by work motivation variable while the other $62.6 \%$ is contributed by other variables. Also, the result of qualitative research interviews, observation, and documentation in thirty two regional working units in Sarolangun Regency, Jambi Province, Indonesia, confirms the tendency of the relationship between work motivation and employees' performance. This finding enforces the quantitative research hypothesis results testing that there is a positive significant relationship between work motivation and employees' performance.

The findings obtained in this study indicate that work motivation is the driving force, mobilizing and directing both from within and from outside the individual to act and behave in achieving the stated goals of the organization.

This condition is supported by motivational theories put forward Boldini (2004) which states that motivation is pure impulse that comes from inside a person's willingness to do something desirable. Similarly, the theory of Mc Clelland in Kinicki and Williams (2004) states that motivation is the urge to do things better or more efficient in solving problems to achieve excellence in the tasks assigned. Previous relevant research result has also proved that motivation has a positive influence to performance (Sehfudin \& Mas'ud, 2011). Thus the findings in this analysis further supports previous findings on the positive influence of work motivation to performance.

\subsection{Interaction of Training Effectiveness, Emotional Intelligence, and Work Motivation on Performance}

When tested together, hypothesis testing results show that there is a significant relationship among training effectiveness, emotional intelligence and work motivation to performance. The regression equation generated is $\hat{Y}=308,95+0,924 \mathrm{X}_{1}+0,280 \mathrm{X}_{2}+0,155 \mathrm{X}_{3}$ with correlation of coefficient values $=0.932$ and the coefficient of determination $=0.868$. This means that $86.8 \%$ of performance is caused by variables of training effectiveness, emotional intelligence and work motivation while $13.2 \%$ is contributed by other variables not included in the model. As well, the result of qualitative research interviews, observation, and documentation in thirty two regional working units in Sarolangun Regency, Jambi Province, Indonesia, confirms the tendency of the relationship among training effectiveness, emotional intelligence and work motivation to performance. This finding strengthens the quantitative research hypothesis results testing that there is a positive significant relationship among those mentioned variables.

The findings obtained in this study indicate that, if employees in performing their duties and functions are given training to develop competence, and employees are able to develop emotional intelligence to interact well with colleagues as well as feeling comfortable in carrying out their duties because all their needs are fulfilled, then the employees' performance will increase as well. Thus, employees in Sarolangun Regency, Jambi Province, Indonesia who are well-trained, possess high emotional intelligence, supported with good work motivation, will become good performers.

\section{Conclusion}

The findings reveal that there is a positive and significant direct effect of training effectiveness, emotional intelligence and work motivation to performance

Based on the initial design of the constellation between variables, the results showed that the contribution of training effectiveness to performance is $40.8 \%$, emotional intelligence is $30.4 \%$, and work motivation is $37.4 \%$ indicating the highest individual contribution to the employees, performance in Sarolangun Regency, Jambi Province, Indonesia is training effectiveness. When combined together, a contribution of the three variables of training effectiveness, emotional intelligence and work motivation reaches $86.8 \%$ indicating the contribution of other variables not included in the model to predict performance is $13.2 \%$ indicating this model is of good-fit. However, other researchers wishing to conduct similar studies may include other variables such as; performance incentives, human resources development, allowance system, and work commitment.

\section{REFERENCES}

Atta, Mohsin, Muhammad Ather,Dr Maher Bano, Emotional Intelligence and Personality Traits among University Teachers:Relationship and Gender differences, Department of Psychology University of Peshawar, International Journal of Business and Social Science Vol. 4 No. 17 Special Issue - December, 2013. 
Boldini, John, Great Motivation Secret of Greath Leader, New York : Mc Graw-Hill., 2004.

Colquitt, J., Lepine, J. A., \& Wesson, M. J., Organizational behavior: Improving performance and commitment in the workplace. McGraw-Hill/Irwin, 2009.

Gibson, Organizations: Behavior, Structure and Processes. New York: McGraw-Hill, 2012.

Kinicki, A. \& Williams, B.K. Management, a Practical Introduction Mc Graw-Hill International, 2008.

Maria Jose Sanchez-Ruiz, Juan Carlos Perez-Gonzalez, \& K. V. Petrides. Trait Emotional Intelligence Profiles of Students from Different University Faculties. Australian Journal of Psychology, Vol. 62, No. 1, March 2010.

McShane and Von Glinow, Organizational Behavior, Emerging Knowledge and Practice for the Real World,New York: McGraw-Hill Irwin, 2010.

Noe, R. A., John R. Hollenbeck, Barry Gerhart, Patrick M. Wright Fourth Edition Fundamentals of Human Resource Management,New York: McGraw-Hill/Irwin, 2011.

Sehfudin, Arif, and Fuad MAS'UD. Pengaruh Gaya Kepemimpinan, Komunikasi Organisasi Dan Motivasi Kerja Terhadap Kinerja Karyawan (Studi Pada Pt Bank Tabungan Pensiunan Nasional Cabang Semarang). Diss. Universitas Diponegoro, 2011.

Sultana, Afshan, Sobia Irum., Kamran Ahmed and Nasir Mehmood.Impact of training on employee performance: a study of telecommunication sector in Pakistan. Interdisciplinary Journal of contemporary research in business 4.6 (2012): 646. 